\title{
PENGEMBANGAN BAHAN AJAR BERBENTUK MAJALAH ELEKTRONIK \\ BERBANTUAN FLIP BOOK MAKER MATERI TEKS FABEL KELAS VII \\ DI SMP NEGERI 37 MEDAN TAHUN PEMBELAJARAN 2018/2019
}

\author{
Oleh \\ Ade Fitri Simamora (adefitris1998@gmail.com) \\ Rosmaini (rosmainifadil@yahoo.com) \\ Universitas Negeri Medan
}

\begin{abstract}
ABSTRAK
Penelitian ini bertolak dari masalah keterbatasan bahan ajar berupa buku paket bahasa Indonesia yang tidak dimiliki oleh semua siswa. Untuk mengatasi permasalahan tersebut, diperlukan pengembangan bahan ajar yang menarik yang harus disusun sesuai Kompetensi Dasar Kurikulum 2013. Penelitian ini bertujuan untuk (1) mengembangkan bahan ajar sehingga menghasilkan produk bahan ajar berbentuk majalah elektronik berbantuan flip book maker pada materi teks fabel kelas VII di SMP Negeri 37 Medan, (2) mendeskripsikan kelayakan majalah elektronik sebagai bahan ajar materi teks fabel di kelas VII di SMP Negeri 37 Medan. Penelitian ini menggunakan metode Research and Development (R\&D) dengan menggunakan model Borg and Gall, yaitu potensi dan masalah, pengumpulan data, desain produk, validasi desain, perbaikan desain, uji coba produk, revisi produk, uji coba pemakaian, revisi produk, hasil produk. Adapun hasil penelitian ini ialah telah dihasilkan produk bahan ajar berbentuk majalah elektronik berbantuan flip book maker pada materi teks fabel kelas VII dengan persentasi kelayakan 76,19\% dari ahli materi, $81,33 \%$ dari ahli desain, 76,25\% berdasarkan respon guru, serta $72,41 \%$ berdasarkan respon siswa. Sehingga dapat disimpulkan bahwa produk pengembangan bahan ajar berbentuk majalah elektronik berbantuan flip book maker layak digunakan sebagai bahan ajar.
\end{abstract}

\section{Kata Kunci : Majalah Elektronik, Flip Book Maker, Teks Fabel, Model Borg and Gall}

\section{A. PENDAHULUAN}

Kegiatan pembelajaran adalah suatu kegiatan yang melibatkan pendidik dan peserta didik dalam suatu interaksi dalam upaya mencapai tujuan pendidikan. Untuk mencapai tujuan pendidikan, guru memiliki peran yang sangat penting dalam merancang pembelajaran yang bermutu agar peserta didik dapat mengembangkan kemampuan dan potensi yang dimilikinya. Peran guru untuk menciptakan pendidikan yang bermutu bukan hanya pada saat pembelajaran berlangsung, namun juga sebelum pelaksanaan kegiatan belajar mengajar dilaksanakan. Dengan kata lain, guru juga harus memperhatikan kualitas dalam menyusun 
perencanaan mengajar berdasarkan kebutuhan peserta didiknya. Salah satu yang termasuk di dalamnya ialah mempersiapkan bahan ajar sesuai dengan kebutuhan peserta didik.

Sebagai salah satu dari komponen-komponen pembelajaran, bahan ajar juga termasuk komponen yang harus memiliki kualitas yang ditinjau dari kelayakan isi, bahasa, dan penyajian. Prastowo (2015 : 17) memberikan pengertian bahwa bahan ajar adalah segala bahan (baik informasi, alat, maupun teks) yang disusun secara sistematis, yang menampilkan sosok utuh dari kompetensi yang akan dikuasai peserta didik dan digunakan dalam proses pembelajaran dengan tujuan perencanaan dan penelaahan implementasi pembelajaran.

Sekolah telah menyediakan berbagai bahan ajar, misalnya, LKS, buku cetak, atau modul yang diterbitkan oleh berbagai instansi. Ketersedian bahan ajar yang terdapat di sekolah dianggap sebagai satu-satunya bahan ajar yang digunakan guru dan siswa dalam proses belajar mengajar. Hal inilah yang menyebabkan pengembangan bahan ajar masih jarang dilakukan oleh guru padahal mengembangkan bahan ajar itu sendiri telah menjadi tuntutan dan berkaitan dengan kemampuan pedagogik serta kemampuan profesional seorang guru sebagaimana yang telah tertera dalam lampiran Permendiknas Nomor 16 Tahun 2007 tentang Standar Kualifikasi Akademik dan Kompetensi Guru bagian B.

Pengembangan bahan ajar juga dinyatakan sesuai dengan amanah Undang-undang Guru dan Dosen Nomor 14 Tahun 2005 pada pasal 10 dinyatakan bahwa kompetensi yang harus dimiliki guru adalah : a) kompetensi pedagogis, b) kompetensi kepribadian, c) kompetensi sosial, dan d) kompetensi profesional. Berdasarkan empat kompetensi tersebut, maka kompetensi inti yang wajib dimiliki seorang guru adalah : (1) mengembangkan kurikulum yang terkait dengan bidang pembelajaran yang diampu, (2) menyelenggarakan kegiatan pembelajaran yang mendidik, (3) mengembangkan materi pembelajaran yang diampu secara kreatif, dan (4) memanfaatkan teknologi informasi dan komunikasi untuk berkomunikasi dan mengembangkan diri.

Walaupun telah menjadi tuntutan dan memiliki manfaat untuk membantu siswa dan guru dalam proses pembelajaran, namun guru masih jarang secara inisiatif mengembangkan bahan ajar. Permasalahan ini ditemukan peneliti ketika melakukan observasi prapenelitian di SMP Negeri 37 Medan. Bahan ajar yang digunakan di sekolah ini masih bersifat konvensional dan terbatas, artinya bahan ajar berupa buku paket yang diterbitkan oleh Kemdikbud dan tidak semua siswa memiliki buku pegangan tersebut. Dampak dari permasalahan ini ialah siswa merasa kesulitan saat mengerjakan pekerjaan rumah sebab tidak memiliki buku pegangan.

Salah satu solusi untuk mengatasi permasalah tersebut ialah dengan memanfaatkan teknologi di era globalisasi dalam bidang pendidikan untuk menciptakan pembelajaran yang 
inovatif dan kreatif, yaitu melakukan pengembangkan bahan ajar yang berbasis elektronik. Bahan ajar elektronik ialah bahan ajar yang memanfaatkan teknologi dalam pengaplikasiannya. Kelebihan bahan ajar ini ialah tampilan yang dapat dibuat kreatif dan lebih mampu menarik perhatian siswa hingga dapat menumbuhkan motivasinya dalam proses belajar mengajar. Selain itu bahan ajar berberbasis elektronik juga dapat diakses kapan saja dengan mudah dan dapat dimiliki oleh semua siswa.

Bahan ajar yang tidak konvensional adalah bahan ajar yang berbentuk majalah. Hasil penelitian dari Subiki, dkk (2015) menyimpulkan "Perlunya diadakan inovasi bahan ajar berbasis majalah yang menarik minat siswa untuk belajar, karena siswa cenderung menyukai bacaan yang menarik dengan sedikit uraian dan banyak gambar atau warna.” Majalah juga tidak hanya berbentuk sebagai media cetak, sebab teknologi juga sudah mengembangkan majalah dalam bentuk elektronik, yang disebut majalah elektronik, yang pembuatan dan pemakaiannya lebih efektif dan relatif mudah. Menurut Poerwadarminta (2000:36) majalah diartikan sebagai "Surat kabar berkala, surat kabar yang terbit mingguan, bulanan, dan sebagainya." Poerwadarminta juga menjabarkan bahwa majalah adalah suatu tempat di mana ilmu pengetahuan serta informasi berkumpul.

Sebagai bahan ajar, suatu majalah memiliki format atau sistematika. Penelitian ini menghasilkan produk majalah elektronik yang memiliki format sesuai dengan penelitian terdahulu oleh Kurniawati (2015). Adapun format bahan ajar berbentuk majalah, ialah (1) Kover atau sampul yaitu bagian yang terdapat di bagian awal yang memuat judul majalah dan topik yang akan dibahas, (2) Redaktur yaitu bagian yang memuat nama penulis, dosen pembimbing, serta ahli validator, (3) Daftar isi yaitu bagian yang memuat letak halaman dari judul bahasan yang dimuat di majalah, (4) Halaman isi yaitu bagian ini memuat rubik materi pelajaran serta latihan-latihan yang akan dipaparkan sesuai dengan Kompetensi Inti dan Kompetensi Dasar, dan yang terakhir (5) Sampul belakang.

Salah satu materi dalam pembelajaran bahasa Indonesia kelas VII kurikulum 2013 edisi revisi 2017, ialah materi teks fabel yang terdapat pada KD 3.11, 4.11, 3.12, dan 4.12. KD 3.11 berisi mengidentifikasi informasi tentang fabel/legenda daerah setempat yang dibaca dan didengar. KD 4.11 berisi menceritakan kembali isi fabel/legenda daerah setempat. KD 3.12 berisi menelaah struktur dan kebahasaan fabel/legenda daerah setempat yang dibaca dan didengar. KD 4.12 berisi memerankan isi fabel/legenda daerah setempat yang dibaca dan didengar. 


\section{B. KAJIAN TEORI}

Teks fabel ialah teks yang berupa cerita-cerita yang menjadikan binatang sebagai tokoh yang memiliki watak seperti manusia. Pembelajaran teks fabel tidak hanya untuk memberikan hiburan namun juga bertujuan untuk mendidik, membentuk kepribadian, dan menuntun kecerdasan emosional peserta didik dengan menanamkan nilai-nilai karakter melalui cerita. Pernyataan ini selaras dengan pendapat Sugihastuti (2013 : 26) yang menyatakan bahwa teks fabel sebagai teks persuasif, berarti teks fabel mengajarkan sesuatu yang meyakinkan, yang kadang kala bersifat humor, mengharukan, dan yang memberi informasi. Fabel sebagai teks persuasif mementingkan pengubahan agar pembaca menerima pesan moral oleh teks. Dengan kata lain, melalui teks fabel peserta didik diharapkan mampu menerapkan karakter-karakter yang baik dalam kehidupannya sehari-hari.

Pengembangan bahan ajar inovatif dan kreatif dalam bentuk majalah elekronik pada materi teks fabel perlu untuk dilakukan agar dapat membuat siswa berminat dalam pembelajaran teks fabel. Dengan adanya ketertarikan tersebut, siswa akan lebih mudah dalam menemukan nilai-nilai yang terkandung dalam cerita fabel, sehingga guru dapat dengan mudah mengarahkan mereka untuk menerapkannya dalam kehidupan sehari-hari.

Untuk membuat majalah elektronik, dibutuhkan perangkat lunak atau software. Ada banyak perangkat lunak yang dapat digunakan salah satunya ialah Flip Book Maker atau juga disebut dengan disebut Kvisoft Flip Book Maker. Flip Book Maker ialah aplikasi untuk membuat majalah elektronik dengan tampilan yang menarik. Selain itu, aplikasi ini juga menyediakan fitur audio dan visual yang dapat dimanfaatkan guru untuk menciptakan suasana belajar yang lebih menyenangkan. Flip Book Maker banyak digunakan banyak orang untuk membuat majalah ataupun buku elektronik karena penggunaannya yang tidak sulit dan dapat digunakan secara luring atau offline tanpa memerlukan jaringan internet.

Penelitian ini didukung oleh hasil penelitian terdahulu oleh Muhammad, $d k k$ (2018) dengan judul penelitian "Pengembangan Bahan Ajar Majalah Elektronik Fungi untuk SMA Kelas X”. Adapun penelitian tersebut mengacu pada fase model pengembangan ADDIE. Subjek uji coba majalah elektronik fungi dalam penelitian ini adalah peseta didik kelas X IPA di SMA Islam Al-Azhar Kota Makasar berjumlah 14 orang. Hasil dan proses penelitian ini menunjukkan majalah elektronik fungi telah diperoleh dengan kategori valid, praktis, dan efektif melalui 5 tahap, yaitu (1) analysis, (2) design, (3) development, (4) implementation, (5) evaluation. Kevalidan majalah elektronik dilihat dari nilai rata-rata validasi oleh dua validator yaitu sebesar 3, 49 (valid). Hal ini didukung oleh hasil analisis respon guru yang sangat positif dengan nilai $87,98 \%$, rata-rata nilai respon peserta didik sebesar $79,59 \%$ berada 
pada kategori positif, dan rata-rata total terlaksana pembelajaran sebesar 1,58 yang berada pada kategori terlaksana seluruhnya serta hasil belajar seluruh peserta didik mencapai standar kelulusan hasil belajar.

Penelitian ini juga didukung oleh penelitian oleh Wibowo, et al (2018) dengan judul penelitian "Pengembangan Bahan Ajar Menggunakan Aplikasi Kvisoft Flipbook Maker Materi Himpunan”. Adapun hasil dari penelitian ini menunjukkan bahwa nilai kelayakan oleh ahli materi materi mendapat skor rata-rata 3,23 dengan kriteria baik dan nilai kelayakan oleh alih media dengan skor rata-rata 3,28 dengan kriteria sangat baik, sedangkan nilai kelayakan oleh alih bahasa mendapat skor rata-rata 3,02 dengan kriteria baik. Respon peserta didik sangat menarik, dengan pencapaian skor rata-rata 3,33 uji coba kelompok kecil dan pencapaian skor rata-rata 3,49 uji coba lapangan, respon uji coba guru sangat menarik dengan pencapaian skor rata-rata 3,64. Ini menunjukkan bahwa produk penelitian dianggap layak sebagai bahan ajar.

Berdasarkan uraian di atas, peneliti bermaksud melakukan penelitian pengembangan yang berjudul "Pengembangan Bahan Ajar Berbentuk Majalah Elektronik Berbantuan Flip Book Maker Materi Teks Fabel Kelas VII di SMP Negeri 37 Medan Tahun Pembelajaran 2018/2019".

\section{METODE PENELITIAN}

Penelitian ini dirancang dengan menggunakan metode penelitian dan pengembangan (Research and Development/R\&D) dengan model pengembangan Borg and Garl (Sugiyono, 2018 : 298). Penelitian ini dilakukan di kelas VII SMP Negeri 37 Medan yang terletak di Jalan Timor No. 36B Medan. Teknik pengumpulan data pada penelitian ini dengan menggunakan angket (kuisioner) yang diberikan kepada validator ahli materi dan media serta angket respon guru dan siswa. Selanjutnya data yang diperoleh akan dikualifikasikan dengan mencari persentase seluruh aspek dengan menggunakan rumus skala likert, yaitu

$$
\mathrm{PPV}=\frac{\sum \mathrm{SV}(\mathrm{R})}{\sum N T(R)} \times 100 \%
$$

Keterangan :

PPV $\quad=$ Nilai validitas

$\sum \mathrm{SV}(\mathrm{R})=$ Jumlah skor jawaban validator dan responden

$\sum \mathrm{NT}(\mathrm{R})=$ Jumlah nilai tertinggi validator dan responden

Persentasi skor yang diperoleh selanjutnya diukur dengan menggunakan interpretasi skor untuk skala Likert yang dapat dilihat pada tabel 1 berikut. 
Tabel 1

Klasifikasi Penilaian Kelayakan

\begin{tabular}{c|c|c}
\hline Rentang Persentase Skor & Interval Skor & Kategori \\
\hline $81 \%-100 \%$ & $81-100$ & Sangat Layak \\
\hline $61 \%-80 \%$ & $61-80$ & Layak \\
\hline $41 \%-60 \%$ & $41-61$ & Cukup Layak \\
\hline $21 \%-40 \%$ & $21-40$ & Kurang Layak \\
\hline $0-20 \%$ & $0-20$ & Tidak Layak \\
\hline
\end{tabular}

Sumber : Riduwan (Putri, 2017)

\section{HASIL DAN PEMBAHASAN}

\section{Hasil Penelitian}

Hasil penelitian pengembangan yang dilakukan peneliti ini adalah menghasilkan bahan ajar majalah elektronik dengan menggunakan aplikasi flip book maker. Penelitian dan pengembangan ini dilakukan dengan menggunakan prosedur pengembangan Borg and Garl (Sugiono, $2018: 298$ ).

\section{Potensi dan Masalah}

Pada tahap yang pertama, peneliti melakukan observasi serta wawancara untuk mengetahui masalah serta potensi yang terdapat pada sekolah. Masalah yang terdapat dalam penelitian ini ialah buku paket Bahasa Indonesia yang digunakan sebagai bahan ajar utama dalam proses pembelajaran merupakan buku bantuan yang diterbitkan oleh lembaga resmi Kemendikbud. Buku paket tersebut dipinjamkan secara gratis bagi peserta didik namun tidak dimiliki oleh semua siswa. Namun demikian, sekolah menyediakan infokus sebanyak tiga buah sebagai fasilitas. Hal ini dapat menjadi potensi untuk mendukung penerapan penelitian pengembangan bahan ajar majalah elektronik yang dapat menjadi solusi dalam keterbatasan bahan ajar yang terdapat di sekolah.

\section{Pengumpulan Data}

Pengumpulan data pada penelitian ini ialah dengan mencari berbagai referensi seperti penelitian-penelitian sebelumnya yang relefan melalui jurnal. Hasil yang telah ditemukan ialah, pengembangan bahan ajar berbentuk majalah, pengembangan bahan ajar berbantuan flipbook maker, ataupun juga pengembangan bahan ajar elektronik telah dilakukan sebelumnya dan mendapatkan hasil validasi yang layak. Selain itu, peneliti juga melakukan pencarian informasi yang terdapat di internet dan buku-buku tentang cara menggunakan 
software corel draw dan juga flipbook maker yang digunakan untuk menciptakan bahan ajar majalah elektronik.

\section{Desain Produk}

Pada tahap ini peneliti merancang dan membuat produk yaitu bahan ajar berbentuk majalah elektronik dengan menggunakan aplikasi corel draw dan flip book maker yang berfungsi untuk mendesain bentuk sampul, mengatur tata letak gambar serta tulisan dan menghasilkan produk bahan ajar. Adapun bagian yang dihasilkan ialah halaman sampul, halaman kompetensid dasar, bagian konten atau isi materi, bagian contoh-contoh, dan terakhir adalah bagian latihan.

\section{Validasi Desain}

Validasi desain dilakukan bersama ahli materi dan ahli media untuk menguji kelayakan bahan ajar yang telah didesain. Pada tahap ini, validator ahli berikan kuesioner terkait kelayakan produk bahan ajar yang telah dikembangkan. Hasil dari tahap ini ialah kritik dan saran terhadap produk yaitu menambahkan halaman redaktur dan daftar isi sehingga produk bahan ajar majalah elektronik sesuai dengan sistematika majalah.

\section{Revisi Desain}

Setelah melalui tahap validasi yang pertama, selanjutnya peneliti melakukan revisi sesuai kritik dan saran oleh validator. Perbaikan tersebut dapat dilihat pada gambar berikut :

\section{Gambar 1}

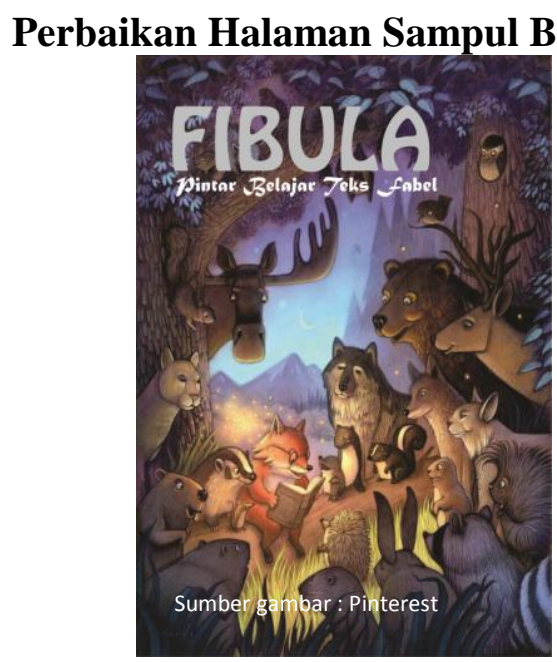

(Sebelum Revisi)

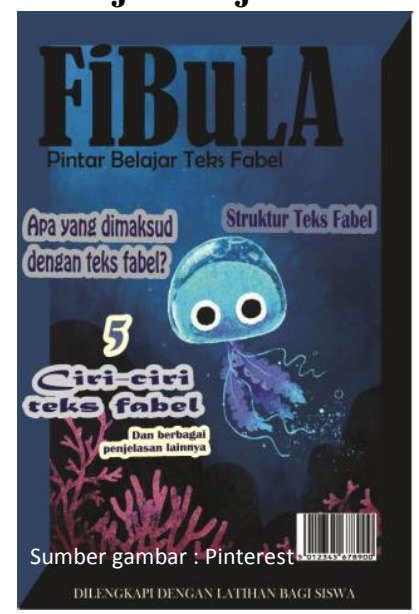

(Sesudah Revisi)

\section{Gambar 2}

Penambahan Halaman Redaktur dan Daftar Isi 


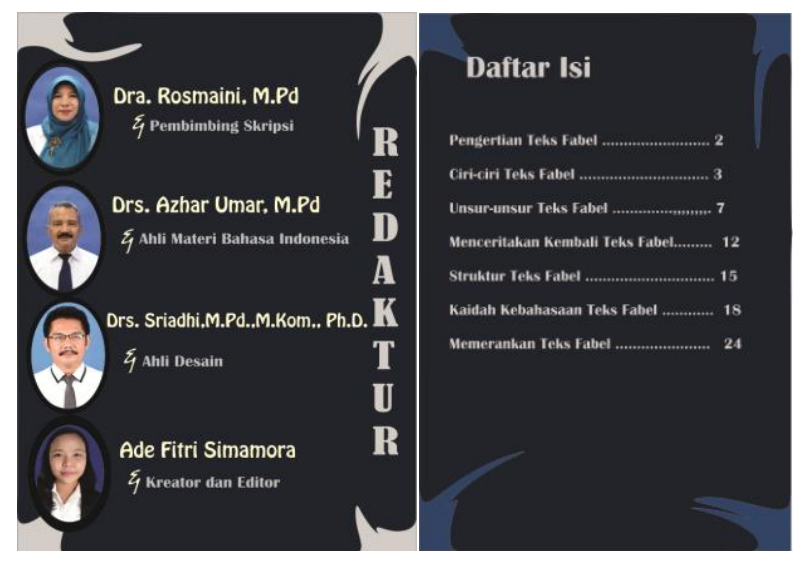

Gambar 3

Perbaikan Desain pada Materi Unsur-unsur Teks Fabel

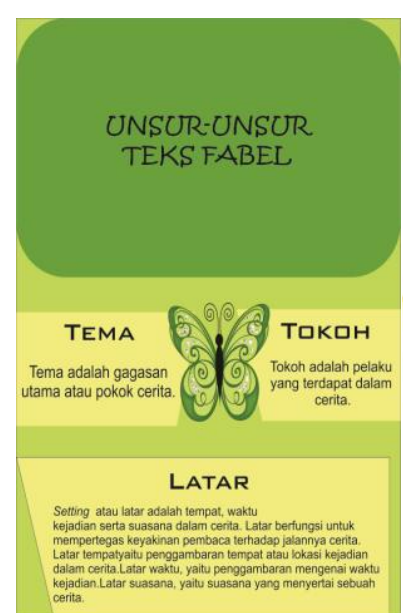

(Sebelum Revisi)

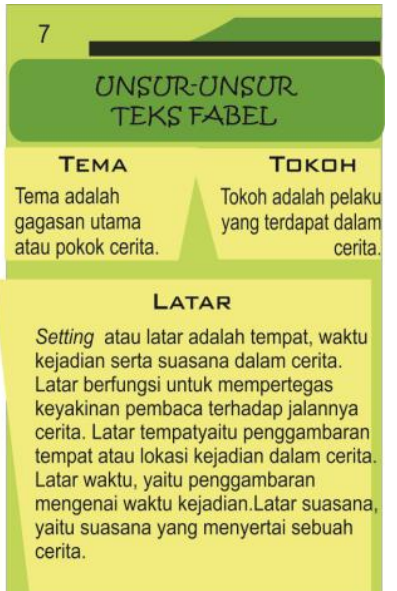

(Setelah Revisi)

Gambar 4

\section{Penambahan Latihan}

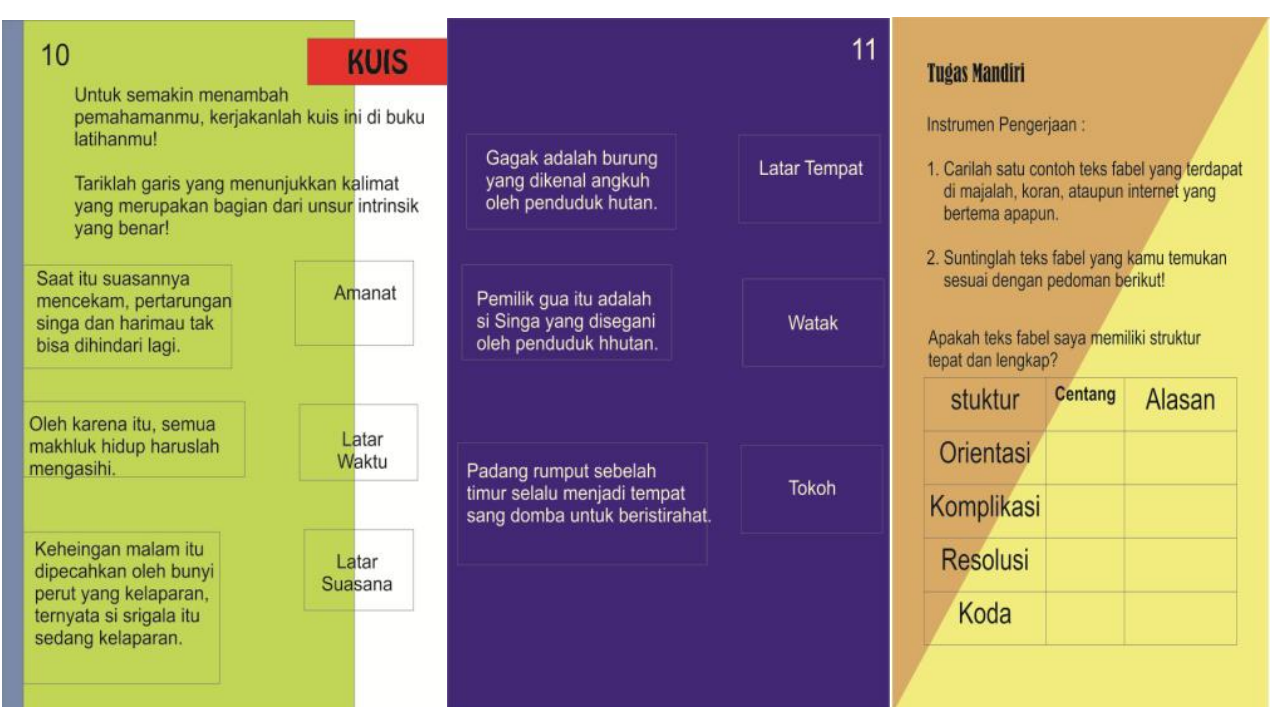


Produk yang telah diperbaiki tersebut kemudian diuji coba kembali oleh ahli materi dan ahli desain dengan mengisi kuesioner validator yang disediakan. Hasil yang diperoleh dengan menggunakan rumus skala likert dapat dilihat pada tabel berikut.

\section{Tabel 3}

Hasil Uji Coba Kelayakan Ahli

\begin{tabular}{c|c|c}
\hline Validator & Persentase & Kategori \\
\hline Ahli materi & $76,19 \%$ & Layak \\
\hline Ahli desain & $81,33 \%$ & Sangat Layak \\
\hline
\end{tabular}

\section{Uji Coba Produk}

Berdasarkan uji kelayakan oleh para ahli, maka produk bahan ajar majalah elektronik dapat digunakan untuk uji coba produk. Uji coba produk dilakukan dalam skala kecil. Pelaksanaan tahap ini ialah dengan menampilkan produk di depan kelas dan memberikan angket respon terhadap sepuluh orang siswa dan satu guru bidang studi. Hasil uji skala kecil ialah perbaikan sesuai kritik dan saran yang diberikan oleh guru bidang studi dan peseta didik. Adapun hasil kelayakan berdasarkan angket responden guru dan peserta didik dapat dilihat pada tabel berikut.

\section{Tabel 4}

Hasil Uji Coba Skala Kecil

\begin{tabular}{c|c|c}
\hline Responden & Persentase & Kategori \\
\hline Guru bidang studi & $73,75 \%$ & Layak \\
\hline Peserta didik & $72,82 \%$ & Layak \\
\hline
\end{tabular}

\section{Revisi Produk}

Pada tahap ini, peneliti melakukan perbaikan kembali sesuai kritik dan saran yang dikemukakan oleh responden, yaitu memperbesar ukuran tulisan serta membuat halaman majalah lebih menarik lagi. Hasil perbaikan dapat dilihat pada gambar berikut.

\section{Gambar 5}

\section{Perbaikan Produk}
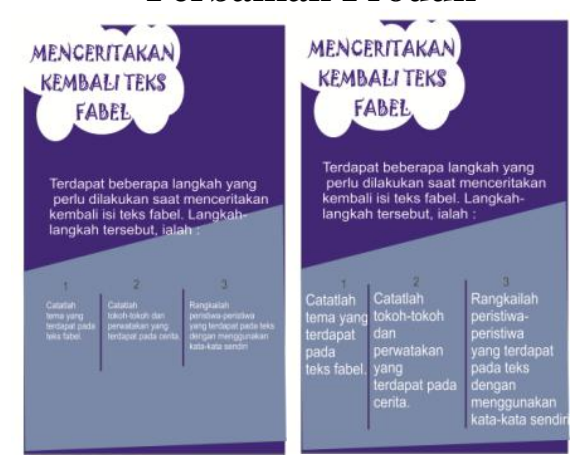

(Sebelum Revisi)

(Sesudah Revisi) 


\section{Uji Coba Pemakaian}

Setelah melakukan perbaikan, peneliti kembali melakukan uji coba pemakaian dengan skala besar yang melibatkan tiga puluh peserta didik dan satu guru bidang studi. Hasil yang diperoleh dapat dilihat pada tabel berikut.

\section{Tabel 3}

Hasil Uji Coba Skala Besar

\begin{tabular}{c|c|c}
\hline Responden & Persentase & Kategori \\
\hline Guru bidang studi & $76.25 \%$ & Layak \\
\hline Siswa & $72.41 \%$ & Layak \\
\hline
\end{tabular}

Pada uji coba kali ini, peneliti juga menerima kritik dan saran dari responden. Adapun saran yang perlu dilakukan ialah membuat majalah menjadi lebih menarik.

\section{Revisi Produk}

Sesuai dengan saran yang diterima peneliti berdasarkan angket respon uji skala besar yaitu membuat majalah menjadi lebih menarik, peneliti memanfaatkan fitur yang disediakan oleh aplikasi flip book maker. Adapun revisi yang dilakukan ialah dengan menambahkan beberapa efek gambar yang bergerak yang telah disediakan aplikasi flip book maker pada beberapa halaman bahan ajar majalah elektronik. Sehingga perbaikan tersebut menjadi produk dari hasil pengembangan bahan ajar.

\section{Hasil Produk}

Tahap terakhir dari pengembangan produk ini ialah hasil akhir yang telah direvisi dan divalidasi oleh ahli materi dan ahli desain. Produk ini juga telah diuji oleh guru dan siswa melalui angket respon yang diberikan. Adapun hasil dari produk pengembangan bahan ajar majalah elektronik pada teks fabel berbantuan flip book maker.

\section{A. Pembahasan}

Penelitian pengembangan produk dilakukan untuk menghasilkan bahan ajar tambahan yang berbentuk majalah elektronik pada materi teks fabel untuk siswa kelas VII SMP. Penelitian ini dilaksanakan di SMP Negeri 37 Medan dengan menggunakan metode R\&D (Research and Development) dengan mengikuti langkah-langkah yang dikemukan oleh Borg and Garl.

Proses uji kelayakan majalah elektronik sebagai bahan ajar termasuk ke dalam tahap pengembangan kelayakan bahan ajar divalidasi oleh ahli materi, ahli desain, respon guru 
bidang studi, dan respon siswa. Masing-masing ahli dan responden mendapatkan angket respon yang pernyataannya disusun sesuai Badan Standar Nasional Pendidikan (BSNP).

Dalam tahap tersebut, majalah elektronik mendapat beberapa perbaikan dan revisi sesuai kritik dan saran yang diberikan oleh validator hingga akhirnya dinyatakan layak untuk diuji coba lapangan. Selanjutnya, peneliti melakukan uji coba di sekolah sebanyak dua kali yaitu uji coba skala kecil yang melibatkan satu guru bidang studi dan sepuluh siswa, dan uji coba skala besar yang melibatkan satu guru bidang studi dan tiga puluh siswa. Untuk mendapatkan data nilai kelayakan bahan ajar majalah elektronik, peneliti menggunakan hasil validasi terakhir dari ahli dan hasil respon uji coba skala besar.

Penilaian terhadap bahan ajar majalah elektronik mendapatakan hasil yang baik dengan kategori "layak". Adapun nilai kelayakan menurut ahli materi ialah 76,19\% dan termasuk kategori layak. Selanjutnya nilai kelayakan menurut ahli desain ialah 81,33\% dan termasuk kategori sangat layak. Selanjutnya nilai kelayakan berdasarkan hasil respon guru bidang studi ialah $76.25 \%$ dan termasuk kategori layak. Dan yang terakhir hasil uji coba produk bahan ajar majalah elektronik berdasarkan hasil respon siswa mencapai hasil rata-rata $72.41 \%$ dan termasuk dalam kategori layak untuk dijadikan bahan ajar. Berdasarkan hal ini, maka dapat diketahui, produk bahan ajar majalah elektronik yang telah dikembangkan secara keseluruhan secara keseluruhan dapat dikategorikan layak digunakan sebagai bahan ajar khususnya pada materi teks fabel bagi siswa dan siswi kelas VII.

\section{E. SIMPULAN DAN SARAN}

Berdasarkan hasil penelitian yang telah diuraikan di atas, maka dapat disimpulkan Penelitian pengembangan mengikuti tahap yang dikemukakan oleh Borg and Gall yaitu mencari potensi dan masalah, pengumpulan data, desain produk, validasi desain, perbaikan desain, uji coba produk, revisi produk, uji coba pemakaian atau yang disebut juga uji coba lapangan atau uji coba skala besar, revisi produk, dan hasil produk. Penelitian ini telah menghasilkan produk bahan ajar majalah elektronik berbantuan flipbook maker pada materi teks fabel yang diperuntukan bagi kelas VII. Produk tersebut memperoleh hasil $76,19 \%$ dari ahli materi dan termasuk kategori layak, $81,33 \%$ dari ahli desain dan termasuk kategori sangat layak, $76.25 \%$ berdasarkan respon guru dan termasuk kategori layak, serta $72.41 \%$ dari siswa dan termasuk dalam kategori layak. Dengan kata lain, produk bahan ajar majalah elektronik yang telah dikembangkan layak untuk digunakan sebagai bahan ajar tambahan. 
Melalui pemaparan tersebut, maka peneliti mengajukan saran kepada guru bidang studi untuk melakukan pengembangan terhadap bahan ajar yang mampu mendukung pelaksanaan pembelajaran.

\section{DAFTAR PUSTAKA}

Kurniawati, Eka. 2015. Pengembangan Majalah Biosmart Invertebrata untuk Meningkatkan Aktivitas dan Hasil Belajar Siswa SMA (Jurnal Online) http://lib.unnes.ac.id/23423/1/SKRIPSI-EkaKurniawati-4401411009.pdf

Muhammad, Nurul Nisa, dkk. 2018. Pengembangan Bahan Ajar Majalah Elektronik Fungi untuk SMA Kelas X (Jurnal Online) http://eprints.unm.ac.id/10364/

Poerwadarminta. 2000. Kamus Besar Bahasa Indonesia. Jakarta : PT Balai Pustaka

Putri, dkk. 2017. Pengembangan e-Magazine pada Materi Larutan Asam dan Basa untuk Siswa Kelas XI MIPA di SMAN 1 Kota Jambi (Jurnal Online) http://repository.unja.ac.id

Subiki, dkk. 2015. Pengembangan Bahan Ajar Fisika Berbasis Majalah Siswa Pintar Fisika (MSPF) Pada Pembelajaran IPA di SMP (Jurnal Online) https://media.neliti.com

Sugiyono. 2018. Metode Penelitian Kuantitatif, Kualitatif, dan R\&D. Bandung : Alfabeta

Wibowo, Edi dan Dona Dinda Pratiwi. 2018. Pengembangan Bahan Ajar Menggunakan Aplikasi Kvisoft Flipbook Maker Materi Himpunan (Jurnal Online) http://ejournal.radenintan.ac.id/index.php/desimal/articel/view/2279 